University of Warwick institutional repository: http://go.warwick.ac.uk/wrap

This paper is made available online in accordance with publisher policies. Please scroll down to view the document itself. Please refer to the repository record for this item and our policy information available from the repository home page for further information.

To see the final version of this paper please visit the publisher's website. Access to the published version may require a subscription.

Author(s): Steve Fuller

Article Title: The Dissent over Dissent over Descent

Year of publication: 2010

Link to published article:

http://dx.doi.org/10.1177/004839311036804

Publisher statement: (C Philosophy of the Social Sciences; SAGE

Publications 


\title{
The Dissent over Dissent Over Descent
}

\author{
Steve Fuller \\ Department of Sociology, University of Warwick
}

I am grateful to my four critics who together attack nearly everything that is attackable in my Dissent over Descent, thereby retaining the original spiritedness of their live presentations at Lund University, Campus Helsingborg, in June 2009. ${ }^{\mathrm{i}}$ Their responses have forced me to delve into some matters more deeply and draw connections that may not have been so obvious from the book. Several of the criticisms overlap, and they are addressed in the main body of this text, often without mentioning the critics' names. However, criticisms unique to particular individuals are addressed in the notes, which are sometimes quite lengthy. Considering the highly charged nature of the topic and approach of Dissent over Descent, a special thanks goes the critics' civility. Even my most hostile opponent, Birgitta Forsman, manages to pay me an unwitting compliment by drawing attention to my alleged 'storytelling' ways, which of course is normally the sense in which Darwin's own scientific modus operandi was supposed to have broken decisively with Newton's (Mayr 1991).

In any case, future historians will have a field day trying to make sense of the fear, loathing and anger that have been generated over the past quarter-century in the various controversies surrounding evolution, divine creation and, most recently, intelligent design as competing accounts for the origins and maintenance of life on earth. As of this writing, these controversies have migrated far beyond their genesis in the Christian American heartland to encompass the world, now sporting even Muslim and Jewish variants. At the public policy level, the animus fuelling the controversies is easily understood: Virtually all the cases involve decisions about what to include in the science curriculum in state-run high schools. Put baldly, what may count as authorised knowledge in official educational settings? The suggestion is that if students are not exposed to one or more of these views, their intellectual capacity to function as citizens will be seriously compromised.

What is immediately apparent about this framing of the problem is that, on the whole, it is not the one that philosophers normally use to decide matters of scientific theory choice.

Philosophers (still) tend to operate with a much more backward-looking and static view of the task. In other words, they presume that competing scientific theories are in a race that ends at the moment a philosopher is taking the decision, in which case the theories' track records are used to justify their respective fates. In contrast, a school board -- or a court considering an appeal to a school board decision -- is focussed on what the next generation should learn in order to deal effectively with the life challenges they are likely to face. In that case, the theories' track records are read for clues to future developments. Nevertheless, it is easy for this prospective judgement to be confused with the philosopher's retrospective one due to a shared problem-framing device: Both presuppose that a forced choice must be made between mutually exclusive alternatives. I have critiqued this presupposition from the earliest days of my social epistemology, partly influenced by Larry Laudan's coinage of 'context of pursuit' in contradistinction to 'context of justification' as a basis for scientific theory choice (Fuller 1993: esp. chap. 4; Laudan 1981).

In any case, philosophers and keepers of the public sphere produce their common problemframing device differently. On the one hand, philosophers sharpen the differences between competing theories that might otherwise overlap in the relevant scientists' minds through feats of definition and deduction that result in some key outcomes of one theory logically excluding those of another. On the other hand, educators and lawyers fixate on the scarcity of 
textbook space and classroom time as the basis for presuming that any attention given to one theory ipso facto takes away from that given to another, which becomes problematic against an implicit assumption of what constitutes a minimum level of attention needed to present a theory adequately. In this respect, a measure of the sensitive nature of today's evolution controversies is that in Kitzmiller v. Dover Area School District, where I served as an expert witness, the bone of contention was the requirement that science teachers read a statement informing students that intelligent design theory exists as an alternative to Neo-Darwinism, while acknowledging the latter's dominant position in contemporary biology. The teachers were not forced to teach intelligent design, and certainly not prohibited from teaching evolution.

The artificial character of both the philosophical and the political problem-framing devices should be obvious. Nevertheless, there are reasons for promoting the artifice. In the case of the anti-evolutionists, the reasons relate to their increasing self-description as 'antiDarwinists', mindful of the significant philosophical differences amongst various theories of evolution. In particular, Darwinian natural selection purports to be a universal process that affects all forms of life equally. Darwin believed not only that our physical morphology and mental dispositions bear witness to our evolutionary past, but also that our knowledge of such matters, albeit unique to Homo sapiens, does not necessarily confer on our species any longterm survival advantage. Unlike such architects of the so-called Neo-Darwinian synthesis from the 1930s and 1940s as Theodosius Dobzhansky and Julian Huxley, Darwin himself did not believe that humans could ever take sufficient control of the evolutionary process to reduce natural selection to a version of the breeding practices of artificial selection. (This had been the context in which Darwin's contemporary, Gregor Mendel, discovered the laws of heredity.) More fundamentally, Darwin did not believe that evolution itself is driven by an intelligence with which human intelligence has an elective affinity, let alone by virtue of our intelligence having been created in a deity's 'image of likeness'. Here Darwin broke fundamentally with the original evolutionary theorist, Jean-Baptiste Lamarck (who still believed in God but never managed to persuade his contemporaries that the deity might create by treating life-forms as loaded dice), not to mention the dissenting brand of Christianity in which he himself was raised (Desmond and Moore 2009).

Much of Darwin's pessimism is traceable to an overarching metaphysical indeterminism whose roots are to be found in Epicureanism, a species of naturalism that arose in the wake of the Alexandrian conquest of Athens, which treats stable order as a transient illusion, unnecessary attachment to which is best given over to therapy. From this standpoint, nature's one constant is the ultimate disorganized form of being we call 'death'. Thus, Darwin probably found it grotesque that the leading intelligent design theorist of his day, William Paley, followed fellow Anglican minister Thomas Malthus in alleging that long-term positive benefits were to be had in the struggle for subsistence in increasingly populous human societies - namely, the identification of the 'fitter' species members. However, some of Darwin's pessimism about humanity's fate was specific to the human brain's poor design, which allows enlightened scientific ideas to co-exist with rather perverse and self-destructive fixed ideas, the latter being genetic holdovers from a primitive past. In this regard, Darwin repeatedly refused all manner of typically Victorian solicitations -- including from his cousin Francis Galton of eugenics fame - to endorse science-based schemes to promote the human condition, usually on grounds of the greater misery that might ensue for those who are supposed to be helped, as well as the risks to which the lives of animals might be exposed (e.g. by their use in medical experiments). Amongst such dangerous schemes, Darwin even 
included John Stuart Mill's call for easily available contraception advice to prevent unwanted births (Peart and Levy 2008).

For nearly all creationists and many intelligent design supporters, the legally relevant question here is whether restricting publicly funded science instruction to the pronounced anti-humanism of Darwin's theory of biological evolution constitutes an encroachment of the state into matters that are constitutionally delegated to civil society. Thus, the legal mind behind intelligent design theory, Philip Johnson (1991), has accused the singular promotion of Darwinism in schools of fostering a naturalistic religion. And he is literally correct, as long as US courts insist on upholding the idea that science requires a belief that natural history is entirely the result of processes observable today under normal circumstances. This insistence ties 'naturalism' to what in the $19^{\text {th }}$ century was called 'uniformitarianism' but which nowadays might be regarded as a species of 'inductivism'. It harks back to David Hume's rather muted defence of Newtonian mechanics as a mathematically elegant and useful summary of the solar system's regularities - but not a glimpse into the deep causal structure of the natural world - and hence not a basis for launching a design-based argument for God's existence.

Yet, it is also clear that the two most recent revolutions in physics - relativity theory and quantum mechanics - would have been precluded by such 'naturalistic' strictures, had they prevailed in the first quarter of the 20th century, when the epistemic status of the two theories was still very much contested. In both cases, there was general agreement over the relevant mathematics and experimental outcomes. The difficulty was trying to find a physical interpretation that did not entail the suspension of key Newtonian assumptions, which for the previous two centuries had been taken as synonymous with the physics of the everyday world. It is to the great credit of the physics community that by 1930 they embraced challenging conceptions of space, time and cause that broke decisively with what had passed for the so-called 'natural attitude'. To be sure, 'common sense' and 'ordinary language' conceptions of space and time have persisted in philosophy into living memory (e.g. Gale 1967), attempting to show that our normal way of relating to the world presumes the irrelevance if not outright incoherence of technical scientific concepts. Although the US National Academy of Sciences would be the last to see itself in these terms, its rearguard appeal to 'methodological naturalism' as its official ideology continues this embarrassing modern tendency for (some) philosophers to promote the scientific beliefs they inherited as if they were timeless epistemological truths (e.g. Pennock 2010).

In this context, it is easy to appreciate the appeal that the logical positivists and the Popperians - as well as the early Richard Rorty (1965) - made to cutting-edge science as doing a better job than professional philosophy in providing a Kant-style 'anticipation of experience' that defines philosophy at its best. Today's so-called methodological naturalists would be at a loss to deal with such figures. Common to the positivists, the Popperians and Rorty was a radical reading of Kant, in which our concepts riskily stake out the scope of all that there is to know, the empirical details of which would be then filled out by science.

Theories are thus to be understood as hypotheses rather than dogmas, which in turn marks the break point between organized science and organized religion. As Popper especially stressed, science (done well) is simply (well done) philosophy but by technologically enhanced means. From this standpoint, the error committed by most $19^{\text {th }}$ century forms of Kantianism including Comtean positivism - was that they presumed that, in the wake of Newton, the pursuit of knowledge could proceed on less risky foundations than it had in the past. In effect, Kant's 'transcendental deduction' was interpreted as converting Newton's physics into 
metaphysics, which only served to reinforce both philosophy's and science's most conservative tendencies. These philosophers had failed to appreciate a point brought out very well by Bayes Theorem - namely, that it is possible for many knowledge claims to be empirically well-founded if certain theoretical assumptions are true while there remains a strong chance that those assumptions are themselves false.

This historical detour returns to my own interest in promoting intelligent design in schools, which is much more positive than Johnson's original worries about naturalism turning into an established religion. I actually believe that the deep theological roots of intelligent design theory provide a robust basis for perpetuating the radical spirit of inquiry that marks both philosophy and science at its best. Before explicating the import of this proposal, I need to dispose of some practical matters. Much, if not most, criticism of my defence of intelligent design has turned on my alleged - perhaps allegedly deliberate - misunderstanding of what intelligent design is really about. Lazy reviewers of my books have used this gambit to set aside my actual arguments in order to deliver boilerplate accounts of everything that is wrong with their straw construction of the theory (Fuller 2009). Both Shearmur and Inge-Bert Täljedal engage in a charitable version of this behaviour: They believe that what I am proposing is much more interesting and/or reasonable than 'real' intelligent design theory.

Here I must display my true social constructivist colours ${ }^{\mathrm{ii}}$ : I see myself as one of the constructors of intelligent design theory. I am not simply remarking from the sidelines about what others have done or are doing, as a historian or journalist might. Rather I am making a front-line contribution to defining the theory's identity. There are many ways to be involved in such a task. Most obviously one could announce a new scientific finding on behalf of the theory - and perhaps be subject to various forms of censorship and ostracism in the process, or simply be told that there is already a Neo-Darwinian account for the phenomenon. But equally important is to reclaim earlier findings for intelligent design that Neo-Darwinism has illegitimately claimed for itself simply because of the 'winner-takes-all' nature of scientific paradigms, a process that Kuhn legitimated. The fact that even today most work in the disciplines that comprise the Neo-Darwinian synthesis - from palaeontology and ecology to genetics and molecular biology - can be conducted with only the vaguest of references to evolution is a reminder that those on whose shoulders the likes of Richard Dawkins would stand today have operated from a variety of explanatory frameworks, including ones that mix creationist and evolutionary accounts, as well as purely special creationist ones (e.g. Linnaeus, Cuvier, Mendel). ${ }^{\text {iii }}$

Indeed, the seemingly indomitable character of evolutionary theory in biology is based on a threefold illusion, which will inform the discussion that follows: (1) Semantically, 'evolution' is not a univocal term but one whose meaning can be widened (as in 'theistic evolution', 'directed evolution' or even 'creative evolution') or narrowed (as in 'Darwinian evolution'), depending on the argumentative context. (2) Epistemically, the bodies of knowledge used to construct the Neo-Darwinian synthesis can also be used - properly re-interpreted and supplemented by other bodies of knowledge (e.g. engineering) - to form other biological syntheses, including ones that foreground intelligent design. (3) Historically, many, if not most, of the knowledge claims that are now justified 'naturalistically' began life as 'supernatural' hypotheses. It would not be unreasonable to think of 'scientific naturalism' as a retrospective honour bestowed on supernatural hypotheses that have managed over time to command the assent of non-believers. ${ }^{\text {iv }}$ 
In terms of pedagogical implications, my support of intelligent design goes beyond merely requiring that students learn the history and philosophy of science alongside their normal studies. It involves re-engineering the science curriculum so that its history and philosophy falls within its normal remit. ${ }^{\mathrm{v}}$ In this I could not agree more with Jarvie - and for the reasons he states. However, especially with regard to point (3) above, the devil lies in the detail of the textbooks and curriculum that would claim to make good on this channelling of the supernatural for scientific purposes. On this basis, I did not endorse the Of Pandas and People textbook on offer in the Dover Area School District as fit for purpose. ${ }^{\mathrm{vi}}$

In the United Kingdom, which does not constitutionally separate church and state, the largely public-funded Christian high schools have been receiving and, to some extent, implementing curricular guidance along the lines I now advocate for more than a decade (cf. Jones 1998). The result is that there is no marked difference between the performance of students in yearend science examinations between Christian and secular schools. Indeed, in some institutions, the Christian students performed significantly better. This includes more fundamentalist schools where students were taught Darwinist principles for purposes of passing exams but not as a mandatory belief system to be incorporated into whatever research or policy to which they might someday contribute. An indirect measure of the ideological character of evolutionary theory today is the soreness that Darwinists register about this last point, even though philosophers down through the ages have frequently recommended a hypothetical attitude towards scientific theories. Indeed, as Jarvie rightly emphasizes, a theory cannot be fairly tested unless a clear operational distinction is drawn between knowing its content and believing its truth (cf. Fuller 2008: chap. 1).

Here we move into what may be the most controversial aspect of my position, namely, that the active promotion of a certain broadly Abrahamic theological perspective is necessary to motivate students to undertake lives in science and to support those who decide to do so. In important respects, this cuts against Johnson's original animus for anathematising naturalism as creeping religion. Taken at his word, Johnson wants to return to the US founding fathers' understanding of 'separation of church and state', which was invoked to prevent the establishment of a national religion but without denying religion's role in motivating inquiry and other aspects of human development. For Europeans especially, it is important to recall the highly devolved nature of educational authority mandated by the US Constitution: Individual states (not the federal government) may set standards of achievement, but exactly how they are met - in terms of textbooks and curriculum -- is left to the taxpayers in the respective school districts. Court cases arise only when school instruction appears to contradict what citizens thought they were paying for. ${ }^{\text {vii }}$ For example, most of the plaintiffs listed in Kitzmiller v. Dover Area School District were upwardly mobile liberal parents who reflected Dover's transformation from a rural backwater to a bedroom community for the Pennsylvania state capital. By the same token, we should not be surprised if in the next few years Johnson's worst fears are vindicated by a major lawsuit is brought against some science instructor whose overzealous naturalism leads him to deny divine causation in a public school district whose tax base is funded mainly by religious believers.

However, somewhat ironically, I think Johnson's position underestimates the US founding fathers' interest in promoting a non-denominational but recognisably Abrahamic civic religion. This interest, I believe, persisted well into the $19^{\text {th }}$ and even the $20^{\text {th }}$ centuries. It is arguably evident even today. My guess is that had agreement been reached on the principles of an American civic religion, it would have looked like a version of the 'religion of humanity' that came to be championed by the French republicans, who themselves had been 
inspired by such critical readers of the Bible influential in the American Revolution as Joseph Priestley, Thomas Paine and, indeed, Franklin and Jefferson. ${ }^{\text {viii }}$ However, differences in the inherited styles of Christian worship probably explain why the civic religion idea took hold in Catholic France but not in nonconformist Protestant America. In any case, the persistence of appeals to Biblical authority and divine providence in US political rhetoric is difficult to ignore, not least in the case of Abraham Lincoln, whose willingness to provoke a risky civil war was defended on these terms, even as he studiously avoided church membership and evaded questions of personal faith. Whereas some have read Lincoln cynically, I take him to have been a sincere devotee of that elusive American civic religion.

In Dissent over Descent, I argued that the key Abrahamic residue is the idea that humans are privileged above all other creatures in their capacity to understand and control their place in nature by virtue of having been created in the image and likeness of the creative deity. The residue is one that the Enlightenment retains from Protestantism after having purged latter's adherence to the Bible of its 'corrupt' and 'superstitious' elements. Indeed, the very terms 'Abrahamic' and 'monotheistic' to describe the three religions that descend from the Hebrew Scriptures - Judaism, Christianity and Islam - were Enlightenment neologisms coined in the spirit of trying to capture their common essential truths, which in the future would be taken forward by self-legislating rational beings (Masuzawa 2005). The republican revolt against hereditary monarchy and the scientific revolt against clerical authority were the two main fronts on which this movement proceeded in the $18^{\text {th }}$ and $19^{\text {th }}$ centuries. However, the 'movement', such as it was, was never unified either politically or scientifically, a point conjured up by the names of Comte and Popper - two figures who took their common inheritance in rather opposing directions. Nevertheless, my view is that despite this divergence of paths, the significance that science continues to exert on humanity's selfunderstanding, despite all its failures and disasters, testifies to our lingering sense of theologically based ontological privilege. ${ }^{\text {ix }}$

In short, I believe that there is still something to the Enlightenment idea of a civic religion in which science plays a central role as systematically organized critical rationality. But what remains specifically 'religious' about this 'civic religion'? Two aspects: (1) Science's findings are framed in terms of the larger significance of things, nature's 'intelligent design', if you will. (2) Science's pursuit requires a particular species of faith - namely, perseverance in the face of adversity - given science's rather contestable balance sheet in registering goods and harms. If, in contrast to these two 'religious' senses, we were to value science solely for its practical consequences, then support for science would likely disperse to a variety of client-centred markets, after a while losing all pretence of trying to achieve the ultimately true and comprehensive picture of reality, as the various markets generate niche ontologies and epistemologies tailored to specific client needs. ${ }^{\mathrm{x}}$ This is how sophisticated forms of inquiry have traditionally existed outside the Abrahamic sphere, say, in China (Fuller 1997: chap. 7) ${ }^{\mathrm{xi}}$ After all, reductionism - the signature theory-driven project of modern science -makes sense only if all of reality is presumed to have been constructed by, so to speak, a single hand that happens to resemble our own. In that case, science becomes an exercise in reverse engineering but this time with an eye towards improving or completing what God as opposed to some other human - had designed. ${ }^{\text {xii }}$ Little surprise, then, that reductionism's crisis in light of the irreducibly indeterminate nature of quantum phenomena was widely interpreted as marking a limit to humanity's divine pretensions. Nevertheless, our godlike ambitions were subsequently re-channelled into molecular biology and nowadays inhabit the promissory science of nanotechnology (Fuller 2008: chap. 6). 
In this respect, science education is not only about instilling a certain way of knowing but also of being - namely, as creatures whose knowledge enables us to take greater responsibility for what happens in the empirical world, as we better understand its modus operandi. ${ }^{\text {xii }}$ It was confidence in achieving such a perspective that inspired the US founding fathers to draft a constitution that, through a complex system of separation of powers and checks and balances, would (where possible) anticipate and (if not) correct obstructions to good government, very much in the manner they imagined God to have created Newton's universe (Cohen 1995). Whereas Comte might be guilty of transferring the ritualistic trappings of the Catholic Church to his scientific utopia, Franklin and Jefferson - prodded by Priestley - potentially stood accused of reducing the exercise of Christian faith to the appliance of science. The legacy of this charge is the intensity of the legal disputes relating to the science-religion interface: Are the parties to such cases trying to relieve science of religious superstition or realize religion through scientific inquiry - or both? My own answer, with which I believe the founding fathers would agree, is both. ${ }^{\text {xiv }}$

This is a good point to raise the distinction between the contexts of discovery and justification in scientific inquiry - one that I originally drew in Kitzmiller and has reappeared in my subsequent work on the science-religion interface, something that Shearmur but not Forsman has observed. The distinction in contexts reflects a long-standing interest of mine (e.g. Fuller 2000), which cuts against the post-Kuhnian tendency to deny or blur it by arguing either that scientists can discover only that which is justifiable or that scientific justification consists in an idealised discovery procedure. A sharp distinction is especially useful in discussing the possible role of religion in the science classroom. On the one hand, an Abrahamic framework has served as a powerful heuristic for conceptualising deep causal structures by challenging scientists (e.g. Newton, Faraday, Mendel) to operationalise divine agency in terms of experimental manipulations. On the other hand, when such operationalisations have resulted in robust empirical findings, they have been adopted even by scientists lacking the discoverer's original theistic framework. Taken together, these two points about, respectively, discovery and justification imply that religiously motivated inquirers can produce science worthy of acceptance by those who do not share their beliefs. This is a strong intellectual argument for the explicit discussion of religion in the science classroom - and indeed for encouraging religiously motivated students (at least in the Abrahamic tradition) to enter scientific careers.

What is not licensed is the advocacy of an unconditional religious commitment on the basis of whatever scientific successes resulted from applying a religious belief. However, a grey area is suggested by the very term 'Abrahamic', which as noted above is an Enlightenment coinage designed to locate the rational core common to the three great 'Religions of the Book' that promoted the advancement of science. The suggestion is that, once identified, this core might lay the foundations of a civic religion that could provide a reliable basis for scientific discovery, which in turn would serve to persuade those of other faiths and metaphysical commitments to convert to the civic religion. Starting perhaps with Burtt (1925), historians and philosophers of science have masked the controversial theological animus of this argument - science in the service of proselytism -- by a euphemistic appeal to 'metaphysics' as an ineradicable feature of scientific inquiry. ${ }^{\mathrm{xv}}$ Regardless of whether one believes that certain metaphysical commitments are necessary for the conduct of science, our default sanguine views about science (which I share) presuppose an understanding of its place in the world that goes well beyond what is warranted solely by science's rather chequered track record (Fuller 2010a). ${ }^{\text {xvi }}$ 
Shearmur raises a series of questions concerning my positive views of intelligent design as a scientific research programme, especially in terms of how they might differ from the sheer anti-Darwinism and anti-naturalism that appears to dominate Philip Johnson's agenda. First, I would say that a careful reading of the various historical and contemporary theorists of intelligent design reveals a diversity of opinion about the identity -- or even the identifiability -- of the intelligence informing nature's design comparable to the diversity of processes endorsed by self-avowed 'evolutionists'. It is unfortunate, albeit understandable, that these differences remain largely suppressed in the culture war with the Darwinists. However, I have been quite open about identifying the 'intelligence' of intelligent design with the mind of a version of the Abrahamic God into which the scientist aspires to enter by virtue of having been created in imago dei. This claim implies - in a way that has been very controversial in theology but crucial for the rise of modern science - that human and divine intelligence differ in degree not kind. In terms that the medieval scholastics (especially John Duns Scotus) would have approved, a univocal sense of 'intelligent' is attributed to both God and humans, the only difference being that the former possesses infinitely more than the latter. Thus, to say that God 'intelligently designed' reality is to implicate the deity in a process in which humans, however very imperfectly, also engage. Without admitting this semantic point at the outset, the 'intelligence' behind intelligent design would be mysterious and useless to science.

Yet, it is quite a substantial point. It means that we can directly compare ourselves to God and perhaps even chart our progress towards the deity's perfections (Passmore 1970). This conclusion has been strongly resisted by the Roman Catholic Church, which has taken refuge in Thomas Aquinas' counter-claim that all talk about God (e.g. in the Bible) is merely 'analogical', which is to say, to be taken literally only some of the time but figuratively the rest - in proportions to be determined by approved theological authorities. (Protestant detractors coined the word 'equivocal' for this rather flexible approach to the divine word.) Notwithstanding the role that Thomist analogism has played in the development of model building and testing in science, not least in relation to empirical arguments for design in nature (Hesse 1965), it nevertheless presumed that human thought and language are forever limited in their capacity to capture the structure of reality. The Thomists could not countenance that, in some respects, our minds might literally overlap with that of God's, as in our powers of mathematical reasoning and other forms of a priori knowledge, which the Dominican Thomas' arch-rivals, the Franciscans (e.g. Scotus), had stressed in their peculiar revival of Platonism, which in turn seeded both the Scientific Revolution and the rationalist strain in early modern philosophy. These powers, which Leibniz valorised and Kant ultimately debunked as 'intellectual intuition', were impressive (at least on their face) in allowing us (after Cartesian geometry) to project and (after Newtonian mechanics) to predict vast expanses of physical reality with which we never had - or are ever likely to have - direct sensory contact.

This shift in the status of mathematics from a counting and measuring tool (à la Aristotle) to the vanguard discipline of scientific inquiry was part of the modern era's 're-literalisation' of the world, whereby a renewed sense of the continuity of human numerical and verbal expression with the divine logos resulted in projects relating to the construction of political constitutions and scientific languages, ideally ones with universal scope and coverage. Pace Shearmur, while at least some ancient Greek schools (e.g. Pythagoreans, Platonists) had presumed the mathematical structure of reality, they did not promote mathematics as a universal medium for the public expression and testing of knowledge claims. On the contrary, they treated maths as a cult activity, one that remained impressive but suspicious to the 
general public. The same may even be said of writing (e.g. Socrates' distrust of writing in Phaedrus). This sociological feature of Platonism has been arguably more powerful than its doctrinal content. However, all of this changed with the mass spread of literacy and numeracy during the Protestant Reformation, which served to dissolve, if not quite annihilate, church authority, which had previously held a monopoly on the technologies of thought through, e.g., dictating and teaching in a Latin that very few understood.

However, inspired by Newton's example (especially as elaborated by his friend John Locke), dissenting clerics did not abandon their ambition to inhabit the divine mind. The $18^{\text {th }}$ century pre-history of experimental psychology, today captured by a catchall 'associationism', included a variety of hybrid scientific clerics such as David Hartley, Joseph Priestley and even John Wesley of Methodism fame (if one counts his interest in medicine), who held surprisingly modern views about the capacity of the mind - understood as the nervous system -- to achieve summative, synthetic states of consciousness through what we would now call 'self-organization'. The resulting heightened awareness could be brought on by scientific work, deep introspection, inspired church singing and teaching, and perhaps even electrical stimulation, not to mention caffeine and alcohol use. It was characteristic of what at the time was first called 'enthusiasm', a coinage that in the original Greek means 'divinely inspired' (Brantley 1984).

Even as associationism became increasingly secular and materialistic in its outlook, it continued to carry its original theological animus, with the human mind portrayed as a kind of chief executive, if not chief architect, of reality, whose capacity to synthesise disparate sensory inputs was modelled on God's giving form to unruly matter in the Biblical account of Creation. Versions of this 'transcendental' view of the mind can be found in Kant, Hegel and their followers, typically with God's existence held in 'suspended disbelief'. While the very idea that divine and human minds might mutually illuminate their workings was already heretical in most Christian quarters, still more controversial was the suggestion that human initiative might be necessary to complete the divine plan. In other words, God and humans are not only mutually illuminating but also mutually dependent.

This view led to a distinctive perspective on the problem of free will, one that Shearmur queries in my avowed sympathy for Priestley and Marx. In the default version of the problem, free will appears to constitute a break in the laws that normally govern nature. The model here is God's miraculous intervention, a capacity that the deity enjoys by virtue of having laid down the laws in the first place. The laws and norms of society presume that humans also have a similar capacity - such that we can be held personally responsible when we are found to have acted against them - though the philosophical basis for this intuition has always been obscure. In contrast, for the associationist, free will and determinism are not opposites but alternative aspects of the same thing. In this casting, humanity's free will enables us to bring (God-like) determination to an otherwise indeterminate situation, be it the multiply firing neurons in our brains or the multiple futures into which the past might be projected (Rivers and Wykes 2008: chap. 3). Without such 'self-determination', we would remain animals driven, as Kant would say, 'heteronomously' by our passions.

In this respect, free will does not interrupt but produces determinism: We are entrusted to finish the job that God has started, which amounts to getting our embodied spirits in order so as to get the world in order. (The phrase 'tying up loose ends' is apposite in several senses.) From this perspective, theologians should embrace the prospect of an intelligently designed materialism, as it would allay any doubts that God had failed to discipline matter properly. ${ }^{\text {xvii }}$ 
The more that humanity can realize through its own artifice (i.e. technology) the possibilities in nature that God himself had not already done, the more we are engaged in the outworking of Divine Providence, 'building a heaven on earth' xviii

In this context, classical political economy - especially of the Malthus and Ricardo sort may be seen as proposing a rival philosophy of mind and nature to the relatively passive empiricism championed by, say, Hume. In particular, Malthus and Ricardo, both of whom shared Priestley's Unitarian leanings, characterise humans primarily by their capacities for producing rather than perceiving the world, whereby nature is treated more as raw material to be worked over than something that we are simply disposed to observe. ${ }^{\text {xix }}$ A good way to appreciate the contrast is in terms of how each secularises the category of evil from the original (and near-heretical) science of intelligent design, theodicy, according to which the material character of nature seems to require that divine intentions are realized indirectly, rendering 'the best of all possible worlds' compatible with all manner of horrid events. Corresponding to the empiricist notion of error is the political economy notion of wasteinstead of ratios of hits-to-misses, one is concerned with benefits-to-costs (cf. Wise 1989).

Signs of political economy's activist, even constructivist, approach to reality may be found in Priestley's original discovery of oxygen as 'dephlogisticated air'. Even sympathetic commentators continue to focus on his adherence to the outmoded alchemical concept of phlogiston as preventing him from recognising that he had isolated a chemical element (McEvoy 2010). However, by his own lights, Priestley's experiments were prototypes for technologies capable of purifying naturally occurring air to make it better for human consumption. In other words, he saw himself as refining raw matter, not revealing a preexistent reality. Indeed, he located the benefits of dephlogisticated air in the marketing of soda water as an elixir rather as an opportunity to reconstitute the foundations of chemistry (Johnson 2008: chap. 4).

Together these historical observations provide the rudiments for a unified science of intelligent design that divides into two main branches: divine artifice (aka biology) and human artifice (aka technology) -- the former literally considered as a superior version of the latter, or the latter an inferior version of the former, or perhaps the two artifices co-produced in some way, all depending on one's theological starting point. But the literalness of the comparison, whichever way it goes, is fundamental. ${ }^{\mathrm{xx}}$ Hints of the foundations of such a science may be found in the regulative ideals of reason found in Kant, which William Whewell and successive philosophers in the $19^{\text {th }}$ and $20^{\text {th }}$ centuries expanded into secondorder normative principles of scientific inquiry, such as intelligibility, unity, simplicity, fecundity, breadth, depth, etc. Software engineers - who appear to be the main constituency for intelligent design theory without an obvious theological position these days - speak of 'system quality attributes' as latter-day versions of these of notions. ${ }^{\text {xxi }}$ Such principles are of an abstract psychological nature, defining the parameters of our cognitive horizons, which at the limit results in the ultimate object of knowledge, the point where human and divine minds completely coincide. In short, the foundations of knowledge would be a kind of divine psychology, which is not so very far from James Ferrier's 1854 English coinage of 'epistemology' (Passmore 1966: 52-53), important aspects of which carried through to artificial intelligence research and general systems theory in the second half of the $20^{\text {th }}$ century (e.g. Simon 1977, Rosen 1999), though to lesser extent the branch of academic philosophy today called 'epistemology'. xxii 
Dissent over Descent was written with an eye to reconnecting theology and science, which is to say, with an emphasis on the intelligence behind 'intelligent design'. However, most of the debate in this field has so far centred on the relevant sense of 'design', not least because of the seemingly ineliminable character of design-talk in contemporary biology, which if anything has grown stronger as the work of the discipline has migrated from the field site to the molecular laboratory and computer simulator. In the book, I question the curious NeoDarwinian assumption that because certain evolutionarily stable changes can be made to an organism or a population under the highly constrained (aka intelligently designed) conditions of an experiment or a simulation, it follows that those changes must have also routinely occurred in a more spontaneous fashion for all forms of life over millions or billions of years. Such an assumption would never go unchallenged in the social sciences for our own species over a few hundred or thousands of years (Fuller 2008: chap. 5). Here we see the confidence - some might say hubris - that the combinatorial possibilities of complex molecules conjoined to an indefinitely old Earth have bred in the Darwinised mind. ${ }^{\text {xxiii }}$

Other than whether to take biology's pervasive design talk literally, the most controversial question relating to design in nature concerns the 'units of design': Exactly what sort of thing is supposed to be, in the intelligent design jargon, so 'irreducibly' (Behe) or 'specifically' (Dembski) complex as to imply a designer? William Paley, the historic standard-bearer for intelligent design theory - largely because of the negative example he provided for Darwin proves to have been a transitional figure in the history of design thinking. To be sure, Paley retained the ancient Aristotelian typological perspective, which presumes that every normal member of a recognised species is designed (or 'pre-adapted') for its environment. However, Paley supplemented this with a populational perspective, indebted to his fellow cleric Malthus, which justified differential rates of survival - especially amongst various nations and classes of Homo sapiens - as providing at least indirect lessons in the conduct of life. ${ }^{\text {xiv }}$ Darwin not only abandoned the typological in favour of the populational side of Paley's scheme, but he also divested the populational side of its link to theodicy, reflecting Darwin's unwillingness to credit a Creator who would allow so much wasted life. For Darwin, ever the Epicurean, suffering as such is evil, even were it to come from a deity whose ultimate sense of benevolence is brought about by such cruel means as mass extinction. ${ }^{\mathrm{xxv}}$

It is worth observing that while historians and philosophers of biology such as Ernst Mayr and David Hull have pointed to Darwin's definitive shift from typological to populational thinking about species as constituting the biggest conceptual breakthrough in the history of biology, the shift was inspired by the quantitative precincts of social science - specifically what was first called in the $17^{\text {th }}$ century 'political arithmetic', which by the $19^{\text {th }}$ century was called 'social statistics' (Porter 1986). This is a crucial but underexplored part of the backstory to contemporary intelligent design theory. The heavy involvement of theologians and theologically oriented thinkers in this tradition - not least the Reverend Thomas Bayes should remind us of the substantive role that univocal comparisons between divine and human qualities have played in the rise of modern science. In this respect, the history of statistics can be told as one long attempt on the part of humans to second-guess divine governance for purposes of drawing lessons for human governance. The central source of disagreement in this tradition has been whether long-term statistical tendencies should be taken as themselves the outworking of Divine Providence or signs of an open situation that requires human intervention for God's work to be done. Responses to Darwin's own work parallel the two traditions. The former captures the laissez faire mentality promoted by Herbert Spencer, while the latter corresponds to Francis Galton's eugenics campaign, which reintroduced many of the normative judgements about individuals that had been associated 
with typological thinking (e.g. variation in traits must be properly distributed). As social policies, the former suggested tolerance if not neglect, whereas the latter implied legislation if not coercion.

The larger lesson of the history of statistics for intelligent design is that claims about design are necessarily holistic. Nothing is well or poorly designed as such but only in relation to some overarching ends. Even if, as Paley was inclined to argue, a particular organism appears especially well designed for its native habitat, the organism's design features must be seen as part of an overall plan in which they can be shown to be functional. The proper analogue to his famous found watch on the heath is not an organism but the universe as a whole. ${ }^{\text {xvi }}$ In other words, there is an implicit ecological dimension to intelligent design theory, one that Priestley, for example, exploited when he provided one of the first accounts of photosynthesis -- though in characteristically $18^{\text {th }}$ century form, Priestley's account of the process was mechanical, akin to a factory's production line (Johnson 2008: chap. 2). In that sense, however just or unjust certain states of affairs may seem to us, their true normative status remains an open question until the completion of the divine plan, the 'Final Judgement', as Christians like to say. This fundamental uncertainty about underlying design principles has been instrumental in generating the host of conservative, liberal and radical attitudes that have marked humanity's relationship to the rest of nature in the modern period - each of which offered rather different takes on how the future follows from the past. And just as science has tracked theological positions - both critically and dogmatically - it has tracked these secular ideological ones as well. For better or worse, and perhaps surprising to all concerned, social engineering is a secular offspring of intelligent design theory.

\section{References}

Behe, M. (1996). Darwin's Black Box. New York: Simon and Schuster.

Brantley, R. (1984) Locke, Wesley and the Method of English Romanticism. Gainesville FL: University of Florida Press.

Burtt, E.A. (1925). The Metaphysical Foundations of Modern Physical Science. London: Kegan Paul.

Butterfield, H. (1949). Christianity and History. London: G. Bell and Sons.

Cohen, I.B. (1995). Science and the Founding Fathers. New York: W.W. Norton.

Cremaschi, S. and M. Dascal (1996). 'Malthus and Ricardo on Economic Methodology'.

History of Political Economy 28 (3): 475-511.

Desmond, A. and J. Moore (2009). Darwin's Sacred Cause: Race, Slavery and the Quest for Human Origins. London: Allen Lane.

Fuller, S. (1993). Philosophy of Science and Its Discontents (Orig. 1989). New York: Guilford Press.

Fuller, S. (1997). Science. Milton Keynes UK: Open University Press.

Fuller, S. (2000). Thomas Kuhn: A Philosophical History for Our Times. Chicago: University of Chicago Press.

Fuller, S. (2003). Kuhn vs. Popper: The Struggle for the Soul of Science. Cambridge UK: Icon.

Fuller, S. (2006). The Philosophy of Science and Technology Studies. London: Routledge.

Fuller, S. (2007). Science vs. Religion? Intelligent Design and the Problem of Evolution.

Cambridge UK: Polity.

Fuller, S. (2008). Dissent over Descent: Intelligent Design's Challenge to Darwinism.

Cambridge UK: Icon. 
Fuller, S. (2009). 'Science Studies Goes Public: Report on an Ongoing Performance', Spontaneous Generations 2(1): 11-21.

Fuller, S. (2010a). Science: The Art of Living. Durham UK: Acumen.

Fuller, S. (2010b). 'Humanity without Vico'. History of the Human Sciences 23 Forthcoming.

Gale, R., ed. (1967). The Philosophy of Time. Garden City NY: Doubleday.

Gray, J. (2007). Black Mass: Apocalyptic Religion and the Death of Utopia. London: Allen

Lane.

Hacking, I. (1990). The Taming of Chance. Cambridge UK: Cambridge University Press.

Hesse, M.B. (1965). Models and Analogies in Science. South Bend IN: Notre Dame

University Press.

Johnson, P. (1991). Darwin on Trial. Downers Grove IL: Intervarsity Press.

Johnson, S. (2008). The Invention of Air: A Story of Science, Faith, Revolution, and the Birth of America. New York: Penguin Riverhead.

Jones, A. (1998). Science in Faith: A Christian Perspective on Teaching Science. Bristol UK: Christian Schools' Trust.

Koerner, L. (1999). Linnaeus: Nature and Nation. Cambridge MA: Harvard University Press. Laudan, L. (1981). 'A problem-solving approach to scientific progress'. In I. Hacking, ed., Scientific Revolutions (Oxford: Oxford University Press), pp. 144-155.

Mayr, E. (1991). One Long Argument: Charles Darwin and the Origins of Evolutionary Theory. Cambridge MA: Harvard University Press.

Masuzawa, T. (2005). The Invention of World-Religions. Chicago: University of Chicago

Press.

McEvoy, J. (2010). The Historiography of the Chemical Revolution. London: Pickering and Chatto.

Milbank, J. (1990). Theology and Social Theory. Oxford: Blackwell.

Needham, J. (1976). 'The Evolution of Oecumenical Science: The Roles of Europe and China'. Interdisciplinary Science Reviews 1(3): 202-214.

Noble, D.F. (1997). The Religion of Technology: The Spirit of Invention and the Divinity of Man. New York: Penguin.

Passmore, J. (1966). A Hundred Years of Philosophy. Harmondsworth UK: Penguin.

Passmore, J. (1970). The Perfectibility of Man. London: Blackwell.

Peart, S. and D. Levy (2008). 'Darwin's unpublished letter at the Bradlaugh-Besant trial: A question of divided expert judgment' European Journal of Political Economy 24: 343-353. Pennock, R. (2010). 'Can't philosophers tell the difference between science and religion?: Demarcation revisited'. Synthese 172, forthcoming.

Porter, T. (1986). The Rise of Statistical Thinking. Princeton: Princeton University Press.

Richards, J.R. (2000). Human Nature after Darwin: A Philosophical Introduction. London: Routledge.

Rivers, I. and D. Wykes, eds. (2008). Joseph Priestley: Scientist, Philosopher, and Theologian. Oxford: Oxford University Press.

Rorty, R. (1965). 'Mind-Body Identity, Privacy, and Categories'. Review of Metaphysics 19:24-54.

Rosen, R. (1999). Essays on Life Itself. New York: Columbia University Press.

Simon, H.A. (1977). The Sciences of the Artificial. Cambridge MA: MIT Press.

Wise, M.N. (1989) "Work and Waste: Political Economy and Natural Philosophy in

Nineteenth Century Britain." History of Science 27: 263-301.

Young, B. (2000). 'Malthus among the Theologians'. Clio Medica 59: 93-113. 
Steve Fuller is Professor of Sociology at the University of Warwick. He is mainly known for his work on 'social epistemology', the subject of a quarterly journal he founded in 1987 and the first of seventeen books. His most recent books include The Sociology of Intellectual Life: The Career of the Mind in and around the Academy (Sage, 2009) and Science: The Art of Living (Acumen and McGill-Queens University Press, 2010). He is currently finishing a book on the future of humanity and working on one on the history of epistemology. Address: Department of Sociology, University of Warwick, Coventry CV4 7AL, UK. E-mail: s.w.fuller@warwick.ac.uk.

\title{
NOTES
}

\begin{abstract}
${ }^{\mathrm{i}}$ Special thanks go to Alf Bång and Kicki Erneling of the Institute for Communication Studies for hosting the event and the excellent international summer schools around the 'open society' theme that have taken place over the last five years.

ii I already made my social constructivism explicit in Fuller (2000: Preface).

iii In response to my point that no Nobel Prizes have ever been awarded for distinguished contributions to evolutionary theory, Forsman observes that in fact several evolutionists have won the prize and that the Crafoord Prize has been set up specifically to recognise such contributions. All true but beside the point. The evolutionists won their Nobel Prizes for achievements that stand on their own regardless of the validity of Darwin's theory. This even applies to Dawkins' Oxford mentor, Nikko Tinbergen, whose empirical work in ethology is compatible with a variety of naturalistic explanatory frameworks. Here the contrast with physics is interesting, since some of its Nobel Prizes have been awarded for contributions to unified field theory, which is to say, something of comparable generality to evolutionary theory in biology. If nothing else, Nobel Prize
\end{abstract} committees are consensualist.

iv A good case in point is Newton's treatment of motion as something internal, not external, to matter (aka inertia), which in turn is subject to a principle of constant universal attraction (aka gravity), both of which adhere to strict mathematical laws. This was the physics of spiritual bodies guided by a higher intelligence. It was radically different from the classic Epicurean view of what Hobbes still called the 'state of nature' as successive moments of temporary configurations of material atoms forever in violent motion. While the latter may inspire - as it did in Hobbes - a metaphysics of power and control, only the former offers the prospect of a long-term intellectual project like science that rises decisively above the exigencies of survival. And even if it is true that all supernaturally motivated scientific insights are eventually absorbed into the naturalistic world-view, it does not follow either that the supernaturalism was unnecessary or that naturalism is the final word. Indeed, the secular philosophical position nowadays known as 'scientific realism' retains the supernatural impulse in the form of science's persistent drive towards self-transcendence, as it refuses to rest on its empirical and practical laurels, but rather strives to arrive at an ultimately unified account of reality.

${ }^{\mathrm{v}}$ It is telling that when Forsman recommends a book that incorporates the history and philosophy of science into science teaching, she selects Richards (2000), which basically provides an introduction to the various branches of philosophy as filtered through Neo-Darwinist lenses - a sort of evil twin of a Neo-Thomist textbook, in which the scope for criticism is strongly circumscribed by what are, in effect, naturalised value commitments.

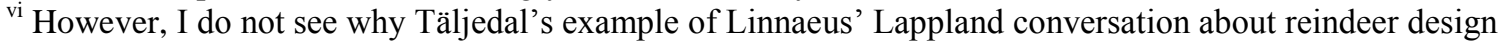
could not be incorporated as part of an intelligent design-oriented science textbook, especially one that placed Linnaeus' scientific project in the context of his overall theological perspective. In this respect, it is not surprising that Linnaeus was dissatisfied with the herdsman's direct appeal to God to explain the reindeer's hoof click, since Linnaeus was one of the major $18^{\text {th }}$ century figures whose systematic studies of nature enabled the transition from theodicy (more about which below) to political economy, perhaps the decisive moment in the secularisation of intelligent design theory. Thus, for Linnaeus, God's signature is most clearly found, not in the detail construction of organisms, but in what he regarded as the hierarchical character of the entire ecosystem, which humans are Biblically to cultivate. Basically Linnaeus identified the increased productivity of nature with the realization of divine goodness (Koerner 1999).

${ }^{\text {vii }}$ Indicative of the American sensibility on this matter is the history of the famed Scholastic Aptitude Test (SAT), the results of which are used by most US universities to set student entry standards. The basic test, mimicking an IQ test in its coverage of verbal and mathematical reasoning, was developed in the early $20^{\text {th }}$ century by a private psychometric firm. By mid-century it had become a convention through mass institutional adoption. Over the years changes to the SAT's form and content have been determined by a combination of feedback from test outcomes and specific court cases (e.g. concerning cultural bias). From a European 
standpoint, this has been a remarkably bottom-up process in which the federal and state governments have been conspicuously passive.

viii The sensibility remains enshrined in France's answer to Westminster Abbey, the Panthéon, which looks suspiciously like the US Capitol.

${ }^{\text {ix }}$ In a new book, I argue that a thoroughgoing atheist who looked at science's overall track record, especially in the $20^{\text {th }}$ century, and was concerned simply with matters of the sustainability of the natural world, would call for a radical scale-back of risky science-driven commitments that would reshape the planet to humanity's convenience (Fuller 2010a: chap. 6).

${ }^{\mathrm{x}}$ Forsman displays a characteristically tone-deaf understanding of the history of philosophy by failing to see that Ockham's Razor was originally applied to show that the language-world relationship is more systematic - and indeed unified - than simply a set of pairwise correspondences between words and things, each explained by a specific mediating concept. In this respect, Ockham's Razor approximates what the $17^{\text {th }}$ century rationalists called 'pre-established harmony', which was treated as a second-order feature of the world that required the existence of God in a way that the explanation of first-order phenomena did not. This in turn justified a unified approach to the pursuit of science, as in the search for overarching natural laws, as opposed to the mapping of irreducibly separate domains of empirical reality that one finds in, say, India, China and even ancient Greece and Rome.

${ }^{\mathrm{xi}}$ Forsman finds it hard to reconcile the 'Eurocentrism' (her term) and the universalism of my approach to science. Part of her problem stems from a failure to appreciate the specificity of 'science' as a form of systematic inquiry with both universalist and unificatory aspirations. Perhaps the most thorough and most sympathetic historian of Chinese civilisation, Joseph Needham, anticipated my conclusion upon considering the uniqueness of the West's 'scientific revolution' (Needham 1976; cf. Fuller 1997: chap. 5). According to Needham (in a part of his argument tends not to be challenged), the Abrahamic self-privileging of Europeans emboldened them to remake (aka rationalise) the entire globe, typically through science-based military innovations that forced the reconfiguration of trading patterns to their advantage, resulting in what Marxists call the 'international division of labour' that characterises capitalism as a 'world-system'. In this respect, there is no denying that the universalisation of 'Eurocentric' science is an outgrowth of Western imperialism, and there is a real debate to be had about whether the resulting benefits outweigh the costs.

${ }^{\text {xii }}$ In this story atomism plays a central yet circumscribed role. The difference between 'atoms' as discussed in ancient and modern atomism is that in the latter case atomic indeterminacy is conceptualised as 'structured' in a way - captured by probability theory -- that overcomes fatalism and encourages scientific inquiry, thus enabling what Ian Hacking (1990) has called 'the taming of chance'.

xiii Lest this seems far-fetched, I have in mind the prospect that we might someday be capable of travelling to and hence intervening in - the affairs of other inhabited planets, perhaps in some other galaxy.

${ }^{\text {xiv }}$ Moreover, this is by no means a uniquely American phenomenon. Both Thomas Huxley and his grandson Julian were concerned with how the spread of Darwinism might affect people's self-understanding and the value they invested in the pursuit of science itself. Whereas Thomas saw humanity's civilising professions - the law, medicine and engineering -- as operating largely in defiance of natural selection, Julian, inspired by fifty years of genetics research, envisaged a 'transhumanist' condition whereby humans would actually take control of natural selection. But in either case, science had a moral obligation to promote a pro-human perspective (Fuller 2007: chap. 5).

${ }^{\mathrm{xv}}$ This is the context to which historian Herbert Butterfield's popularisation of a $17^{\text {th }}$ century 'Scientific Revolution' belongs. He believed that it was both comparable to and continuous with Christianity as a worldtransformative movement. See especially Butterfield (1949), a set of BBC Radio lectures. In this he follows in the footsteps of William Whewell, who crystallised Newton's reputation as the greatest scientist by ranking him just after Jesus in significant humans.

${ }^{x v i}$ Here I may disagree with Jarvie, who not unreasonably is sceptical about the prospect of science itself becoming a kind of religion (aka scientism), which of course had been one of the targets of logical positivist suspicions about 'metaphysics'. I myself canvassed the religiosity of contemporary science in Fuller (2006), which largely casts the 'Science Wars' of the 1990s as a Protestant-style struggle staged by science studies scholars and other postmodernists against authoritative readings of their shared scientific heritage (i.e. not antior even pseudo-science). Jarvie argues that science and religion should remain separate, in part, because of religion's historically documented deleterious effects, many of which are traceable to its demand for unconditional belief, an epistemic attitude that is contrary to the spirit of science. In response, I would first distinguish between first-order scientific theories, which I agree should always be given hypothetical status, and the second-order idea of science as a theoretical project, which may require specific (Monotheistic) religious attitudes. This is because there is more to science than simply a critical, open-minded and rational attitude toward the world. There is also the 'belief', if you will, that a series of errors might bring you closer to the truth, and so the path of inquiry is always worthy of one's perseverance upon which future generations might build. It 
is this belief that elevates science above a mere hobby, and indeed accounts for the unprecedented concentration of material and intellectual resources that, pace Jarvie, has arguably enabled science to do much more damage than religion in its briefer history, if the two are compared in the same sense, namely, as organized activities. (If one imagines religion in terms of its institutional embodiment but science as pure intellectual content, then of course in that question-begging sense religion looks worse than science.) However, this observation is not grounds to shut down science but to recall the doctrine of dirty hands: With the capacity to do much good comes the capacity to do much harm, and the acceptable ratio of costs to benefits is ultimately subject to negotiation and regulation. Moreover, if we consider both science and religion as organized activities, then it is useful to recall the roots of Popper's open/closed society distinction in Henri Bergson's distinction between open and closed religions, as in Protestantism and Catholicism or Buddhism and Hinduism, which in terms of science corresponds to Popper and Kuhn (Fuller 2003: chap. 10). In short, Jarvie's distinction looks compelling because he is comparing open science and closed religion.

xvii This helps to explain Priestley's efforts - amidst of his otherwise deconstructive attitude towards Christian doctrines - to vouchsafe the Resurrection of Jesus, a singular display of God's ability to turn the wayward powers of matter to his decisive advantage.

${ }^{\text {xviii }}$ A very critical history of this impulse - starting from the medieval monastics and ending with the Human Genome Project -- is Noble (1997), the rather darker contemporary political implications of which have been explored in Gray (2007). My own view, however, conforms to the relatively sanguine attitude that we still have towards science and technology, which is not so far from Priestley's (Fuller 2010a). A 'red thread' to follow this history goes through the value connotations surrounding the concept of exploitation, which before Marx was not normally seen as marking a principled (i.e. species-based) difference between the moral treatment of humans and non-humans. Even in John Locke, only members of Homo sapiens with specific legally protected rights as 'persons' are not subject to exploitation, a view that remained in the framing of the US Constitution.

xix On Malthus' early training under Priestley's curriculum at Warrington Academy, see Young (2000). On Ricardo’s Unitarianism, see Cremaschi and Dascal (1996).

${ }^{\mathrm{xx}}$ It implies inter alia at least some commitment to Platonism, whereby one might say that God and humans might instantiate the same form in matter to varying degrees of realization.

${ }^{x x i}$ This is clear from the leading intelligent design blog, www.uncommondescent.com. See especially the 24 May 2009 posting, http://www.uncommondescent.com/intelligent-design/ilities-judging-architecture-anddesign/.

xxii Yes, I mean to say that human minds provide the basis for modelling God's.

xxiii This point recalls the rhetorical blunder that intelligent design champion, the biochemist Michael Behe (1996), committed - which came back to haunt him as an expert witness in Kitzmiller - when he claimed that bacteria are so 'irreducibly complex' (i.e. they were designed fit-for-purpose) that they could not possibly have acquired their mobility function through random mutation and natural selection. Of course, Behe's charge can be easily rebuffed if Darwinian evolution is a probabilistic process that is allowed enough time to run its course with some minimal path dependency built into the outcomes. In that case, there are many possible scenarios by which bacteria could have acquired their form. But instead of questioning whether Neo-Darwinism could provide any account of bacterial mobility, Behe should have asked how they would determine which account was true, thereby calling the theory's falsifiability into doubt. In a sense, then, I agree with Täljedal that antiDarwinist appeals to statistical arguments are bound to prove inconclusive - that is, unless it is also shown (say, by radiometric interpretations of fossils) that the Earth is significantly younger than it is normally thought to be. xxiv Chapter 26 of Paley's Natural Theology, entitled 'On the Goodness of the Deity', is devoted to a defence of Malthus, a controversial figure amongst Christians for his call to end poor laws as a futile exercise in resistance to divine will.

${ }^{x x v}$ Darwin's reasoning here anticipates somewhat Popper's arguments against millenarian utopianism, which would sacrifice many lives in the name of some perfect vision of humanity. Any powerful being willing to use such means would not be worthy of one's allegiance, however noble the aim. However, Jesuits attempted to mitigate such reasoning in the Counter-Reformation by arguing that the material character of Creation generates so much suffering merely as an unintended consequence of divine agency. Of course, this argument has enjoyed its own chequered history as secular theodicy mutated into classical political economy. For a radical theological critique of these developments, see Milbank (1990).

xxvi Arguing against my endorsement of Paley's view that 'design without a designer' is indeed an oxymoron, Täljedal raises the example of the heart as an organ whose design can be explained by its function in our bodies without having to explain how our bodies came to be as they are. Interestingly, the heart was probably the $17^{\text {th }}$ century's favoured example of 'irreducible complexity' in empirical proofs for an intelligent designer. But those who appealed to the example, notably the great Cartesian Malebranche, embedded their arguments in an Abrahamic natural theology, with its prior expectation that human bodies would be especially well designed because of our supreme status in nature. There were no such expectations about the organs of lower creatures, 
which obviously survived but in a lesser state of being, which is to say, not so well designed - a sensibility that lingers in the folk idea that most animals are 'dumb'. A subtle achievement of Darwinism was to overturn these expectations, so that now we presume that all reproductively active species are equally well adapted to their environments, and so their organs can be presumed equally well designed. Such is the blind justice delivered by natural selection. In other words, by abandoning the idea that the human body is the benchmark of God's handiwork, it is no longer necessary - or perhaps even possible - to infer the designer's signature in order to account for the presence of design in the bewildering array of species that have inhabited the planet. 